\title{
TENGSL LESTRARÁHUGAHVATAR OG LESSKILNINGS NEMENDA Á MIDSTIGI GRUNNSKÓLA
}

Rannsóknir sýna að lestraráhugahvöt hefur áhrif á ýmsar hliđar lestrarfærni, svo sem umskráningu, lesskilning og orđaforđa. Börn með litla lestraráhugahvöt lesa minna en jafnaldrar með meiri lestraráhuga og sterk tengsl eru á milli slakrar lestraráhugahvatar, lítils lestrar og lestrarerfiðleika. Markmið rannsóknarinnar var ađ kanna hvernig lestraráhugahvöt birtist í 5. og 6. bekk međal íslenskra nemenda, hvernig hún breytist milli ára og mögulegan kynjamun par á. Einnig að kanna hvort um tengsl milli lestraráhugahvatar og lesskilnings sé ađ ræđa. petta er fyrsta íslenska rannsóknin par sem hlutverk lestraráhugahvatar í lesskilningi međal nemenda á miðstigi grunnskóla er rannsakađ. Pátttakendur í rannsókninni voru valdir með klasaúrtaki, 400 nemendur úr 24 bekkjum í átta skólum á höfuðborgarsvæðinu og Reykjanesi sem svöruðu spurningalista um lestraráhugahvöt í 5. og 6. bekk. Svör peirra voru svo tengd við gengi peirra í lesskilningsverkefnum í 6. bekk. Niðurstöður sýndu að lestraráhugi nemendanna var nokkuð stöðugur milli ára og stúlkurnar höfđu að međaltali meiri lestraráhuga og forđuðust lestur síđur en drengir. Pá spáđi lestraráhugahvöt í 5. bekk fyrir um framfarir í lesskilningi í 6. bekk. Með auknum skilningi á mikilvægi lestraráhugahvatar í læsispróun er hægt að próa leiðir til að auka áhuga með pað að markmiði að auka lesskilning.

Efnisorð: lestraráhugahvöt, lesskilningur, miðstig, kynjamunur, mælitæki

\section{INNGANGUR}

Fyrstu árin í grunnskólanum eru mikilvægur tími í lestrarnámi nemenda. Lestrarframmistađa í fyrstu bekkjunum gefur sterka vísbendingu um gengi í lestri og námi almennt síđar meir (Cunningham og Stanovich, 1997), auk pess sem vísbendingar eru um ađ bilið á milli peirra nemenda sem standa sig best í lestri og peirra sem standa sig verst aukist međ árunum (Cunningham og Stanovich, 1997; McCoach, O'Connell, Reis og Levitt, 2006). í læsi felst bæđi færni í að umskrá texta og skilja innihald hans. Umskráning er í próun á fyrstu stigum lestrarnámsins og veitir mikilvæga undirstöđu fyrir lesskilning (Byrnes og Wasik, 2009). próun lesskilnings tekur lengri tíma og byggist á mörgum samverkandi 
páttum sem tengjast bæđi mál- og vitsmunaproska, sem og annarri námstengdri færni og áhugahvöt (Guthrie og Wigfield, 2000; Pintrich og Schunk, 2002). Rannsóknir benda til pess að lesskilningi unglinga hafi hrakađ undanfarna áratugi og eru íslenskir nemendur par engin undantekning (Almar M. Halldórsson og Ragnar F. Ólafsson, 2016). Petta er áhyggjuefni í ljósi pess að bóklestur er í harđri samkeppni við annars konar afpreyingu og miðla og pví hætt við að lesskilningi barna og ungmenna fari áfram hrakandi (Majid og Tan, 2007). Lestraráhugahvöt (e. reading motivation) er hvatinn sem drífur börn áfram við að lesa, og tengsl hennar við færni nemenda í lesskilningi eru ört vaxandi rannsóknarsvið. Slíkar rannsóknir eru pó enn af skornum skammti á Íslandi. Pví liggja fyrir takmarkađar upplýsingar um lestraráhugahvöt íslenskra grunnskólanemenda og hvernig hún hefur próast. Meginmarkmið pessarar rannsóknar var ađ meta lestraráhugahvöt nemenda í 5. bekk og 6. bekk og skođa möguleg tengsl hennar við gengi peirra á lesskilningsprófi ári síđar. Einnig var kannað hvort niðurstöđur væru ólíkar hjá drengjum og stúlkum.

\section{Lesskilningur}

Hugtakið læsi er vítt hugtak og skilgreint á mismunandi hátt út frá ólíkum sjónarhornum og fræðasviðum. Hér er pađ skilgreint í hefðbundnum skilningi námssálarfræđi sem hugtak um pað hvernig við túlkum ritmálið, lesum pađ, skiljum og ritum (Garton og Pratt, 1989), en einnig sem lykill að lífsgæðum, eins og Menningarmálastofnun Sameinuðu pjóđanna skilgreinir pað (UNESCO, e.d.). Pannig er pað að geta talað tungumál eitt, en að geta lesið, skilið og ritað pað annað. pað er pví tvennt ólíkt að geta talað tungumál og аð geta lesið pað, skilið og ritað. Lesskilningur (e. reading comprehension) vísar til pess að skilja merkingu orđa og texta og byggist hann á málrænum og hugrænum páttum, auk fyrri pekkingar og félagslegs og menningarlegs bakgrunns lesandans (Marzano, 2004; Perfetti, Landi og Oakhill, 2005; van den Broek og Kremer, 2000).

Eitt áhrifamesta lestrarlíkan sem sett hefur verið fram innan lestrarfræða er einfalda lestrarlíkanið (e. simple view of reading) (Hoover og Gough, 1990). Samkvæmt pví byggist lesskilningur á tveimur grunnferlum; umskráningu (e. decoding) eđa lestri stakra orđa (e. single word reading) og málskilningi (e. linguistic comprehension), sem vísar bæđi til skilnings á mæltu og rituðu samfelldu máli (Hoover og Gough, 1990). Hvort ferli um sig er nauðsynleg en ekki nægjanleg forsenda lesskilnings, en pað pýðir að til pess að geta lesið og skilið texta parf lesandinn bæði að umskrá orđin í textanum rétt og af öryggi og skilja orđin, setningarnar og heildina sem pau mynda. Pessi áhersla á samspil umskráningar og málskilnings í lestrarnámi er einn meginstyrkur einfalda lestrarlíkansins og trúlega ástæđa pess hversu útbreitt líkanið er, sérstaklega við rannsóknir og kennslu í lestri byrjenda (Cain, 2010). Málskilningshluti líkansins tekur pó ekki ađeins til áhrifa umskráningar, heldur einnig færni sem tengist orðræðu (e. discourse skills). Pannig reynir lesskilningur til dæmis á getu nemandans til pess að draga ályktanir, samhæfa upplýsingar sem birtast á mismunandi stöđum í textanum og sampætta pær og túlka út frá pekkingu og félagslegum og menningarlegum bakgrunni (Cain og Oakhill, 2006; Perfetti o.fl., 2005; Rapp, van den Broek, McMaster, Kendeou og Espin, 2007). Góđur skilningur krefst pess einnig gjarnan að lesandinn setji sig í mismunandi hlutverk við lesturinn. Lestrarlíkan Lukes og Freebodys (1999), fjögurra leiða líkanið (e. four resources model) gerir til dæmis ráđ fyrir fjórum slíkum; lesandinn parf ađ umskrá textann, átta sig á hvernig hann dregur 
merkingu úr textanum, skilja hvernig hann notar textann og vinna úr honum á gagnrýninn hátt. Notkun námsađferđa skiptir einnig miklu máli fyrir lesskilning, en nemendur međ góðan lesskilning fylgjast með eigin skilningi og bregđast við á viðeigandi hátt pegar upp á vantar (Cartwright, 2009; Oakhill og Cain, 2012). Pannig lesa nemendur ólíka texta með mismunandi hætti, frásögn er lesin með öđrum hætti en t.d. fræđitexti par sem koma parf auga á helstu stađreyndir og muna eđa punkta hjá sér. Við lestur frásagnartexta parf aftur á móti fyrst og fremst að huga að persónum, sögusviđi og framvindu (Snow, 2002).

Lesskilningur byrjar að próast að vissu marki strax í upphafi lestrarnáms, en par sem örugg færni í umskráningu er mikilvæg forsenda lesskilnings (Hoover og Gough, 1990) er hann oftast ekki áhersluatriði í kennslu fyrr en upp úr öđrum bekk (Perfetti o.fl., 2005). Lesskilningur er svo í stöđugri próun í takt við lestrarreynslu og áhuga einstaklingsins (Perfetti o.fl., 2005). Fjöldi alpjóđlegra rannsókna bendir til pess að lesskilningi nemenda á grunnskólastigi hafi hrakađ jafnt og pétt undanfarna áratugi í mörgum löndum, par á međal á Íslandi, annars stađar á Norđurlöndum og í Bandaríkjunum (Almar M. Halldórsson, Ragnar F. Ólafsson og Júlíus K. Björnsson, 2013; Mullis, Martin, Kennedy og Foy, 2007). Samkvæmt mælingum PISA á lesskilningi 15 ára nemenda hefur lesskilningi íslenskra nemenda hrakað mun meira en nemenda annars staðar á Norðurlöndum, að undanskilinni Svípjóđ, en lesskilningur sænskra nemenda hefur verið á hrađri niðurleið síđastliðin ár. Í mælingu sem var gerđ árið 2015 eru pó vísbendingar um aukinn lesskilning sænskra unglinga, og er Ísland pví nú í neđsta sæti af Norđurlöndunum (Almar M. Halldórsson og Ragnar F. Ólafsson, 2016). Pótt ýmsar ástæđur fyrir pessari próun hafi verið nefndar benda rannsóknir ítrekað til pess að minnkandi lestraráhugahvöt og yndislestur međal barna og unglinga tengist sterklega gengi nemenda í lesskilningi (Logan, Medford og Hughes, 2011; Taboada, Tonks, Wigfield og Guthrie, 2009).

\section{Lestraráhugahvöt}

Áhugahvöt (e. motivation) er hugtak yfir vilja fólks til ađ læra og að finnast námið pess virði að leggja eitthvað af mörkum til að takast á við pað (Pintrich og Schunk, 2002). Nemandi með mikla lestraráhugahvöt er tilbúinn að leggja sitt af mörkum í lestrarnáminu, p.e. hann er áhugasamur, athugull, forvitinn og reiðbúinn að lesa. Lestraráhugahvöt er skilgreind sem huglæg ástæða einstaklings til að lesa og á sér margar víddir, t.d. áhuga (e. interest), leikni (e. mastery), sjálf (e. ego) og trú á eigin getu (e. self-efficacy) (Schiefele o.fl., 2012). Fjöldi mælitækja er til sem metur áhugahvöt og eru pau byggð á mismunandi kenningum. Ryan og Deci (2000) skipta til dæmis áhugahvöt í innri áhugahvöt (e. intrinsic motivation), par sem áhugi er á verkefninu og hvatinn er útkoman sjálf, og ytri áhugahvöt (e. extrinsic motivation), sem er andstæðan, p.e. verkefnið er unnið til að fá verðlaun, hrós eđa til ađ forđast refsingu. Nemendur sem eru drifnir áfram af innri áhugahvöt eru líklegri til ađ verđa enn áhugasamari og ganga betur í lestrarnámi en peir sem drifnir eru áfram af ytri áhugahvöt (Logan o.fl., 2011). Ađrar kenningar sem fræđimenn hafa byggt á pegar lestraráhugahvöt er mæld eru til dæmis félagsnámskenning Banduras (1986), sjálfræđiskenningar um hvatningu (Ryan og Deci, 2000) og kenningar Eccles um árangurstengda hvatningu (1983). Einnig hefur lestraráhugahvöt verið skoðuð út frá trú á eigin getu (e. self-efficacy) (Henk, Bottomley og Melninick, 1996) og viðhorfi til lestrar (e. reading attitude) (McKenna, Kear og Ellsworth, 1995). 
Mælitækið sem notað er í pessari rannsókn til pess að meta lestraráhugahvöt međal íslenskra nemenda í 5 . bekk er byggt á kenningu um frammistöđumarkmið (e. achievement goal theory) sem gerir ráđ fyrir ađ áhugahvöt til náms sé best skilgreind sem leit eđa stefna ađ ákveđnu frammistöđumarkmiði (Ames, 1992; Elliott og Dweck, 1988; Nicholls, 1984, 1989). Kenningin lýsir tveimur ađskildum víddum áhugahvatar; verkefnamiðaðri afstöðu (e. task orientation/mastery goal orientation) og sjálfmiðaðri afstöðu (e. ego orientation/performance orientation). Pegar einstaklingur tekur verkefnamiðađa afstöðu, metur hann árangur sinn eftir pví sem honum fer fram og með pví að gera sitt besta pegar verkefni er leyst. Máltækið góđa æfingin skapar meistarann er haft að leiðarljósi. Einstaklingur sem er sjálfmiðađur mælir árangur sinn með pví að bera sig saman við ađra og telur sig ekki hafa náđ árangri nema hann geri betur en ađrir. Honum finnst erfitt að leggja sig fram vegna pess að ef hann parf að leggja meira á sig en aðrir til að leysa verkefni telst pað ekki vera viðunandi árangur. Pessar tvær víddir eru aðskildar en geta einkennt hegðun sama einstaklings. I íslenskum skólum hefur verið lögð áhersla á að nemendur setji sér markmið og taki ábyrgð á eigin námi (Mennta- og menningamálaráđuneyti, 2012) og pví ætti mælitæki um frammistöđumarkmið að henta vel hér á landi til að mæla lestraráhugahvöt.

Fræđimenn hafa rannsakað hvernig lestraráhugahvöt próast í barnæsku og fram á unglingsár og hvort munur sé á peirri próun milli ólíkra hópa. Börn byrja snemma ađ sýna ánægju og vonbrigđi með frammistöđu sína (Dweck, 2002). Í fyrstu bekkjum grunnskóla er áherslan á að læra að lesa en í kringum níu ára aldur breytist áherslan yfir í ađ lesa til að læra. Á pessum aldri breikkar biliđ í lestrargetu nemenda og á sama tíma eru peir farnir ađ bera sig saman við jafnaldra. Með pessum auknu áherslum á lestur virđist lestraráhugahvötin minnka (Wigfield o.fl., 1997).

\section{Tengsl lestraráhugahvatar og lesskilnings}

Rannsóknir sýna ađ áhugahvöt gegnir stóru hlutverki í lestrarpróun hvers barns (Guthrie, Wigfield og VonSecker, 2000; Wigfield o.fl., 1997), par á međal í lesskilningi. Í peim rannsóknum sem gerđar hafa veriđ á tengslum lestraráhugahvatar og lesskilnings kemur í ljós að lestraráhugahvöt spáir fyrir um lesskilning međal barna og ungmenna (Chapman og Tunmer, 1995; Guthrie o.fl., 2007) og að nemendur međ mikla innri áhugahvöt til lestrar skora hærra á mælingum á lesskilningi en nemendur með litla innri áhugahvöt (Logan o.fl., 2011). Rannsóknir sýna enn fremur fram á að sambandið milli lestraráhugahvatar og gengis í lestri og lesskilningi virkar í báđar áttir (Morgan og Fuchs, 2007). Pannig leiðir gott vald nemenda á lestri til aukins áhuga og áhugi á lestri eykur lestrarfærni og lesskilning. Rannsóknir benda til pess ađ áhugahvöt byrji snemma ađ hafa áhrif á lesskilning, jafnvel allt frá upphafi lestrarnáms (sjá t.d. Cartwright, Marshall og Wray, 2015; McElvany, Kortenbruck og Becker, 2008; Wang og Guthrie, 2004). Rétt er bó ađ benda á ađ í sumum rannsóknum hafa ekki fundist slík tengsl í allra yngstu bekkjunum (Chapman og Tunmer, 1995; Hamilton, Nolen og Abbott, 2013; Nurmi og Aunola, 2005). Má e.t.v. rekja pađ til pess að erfitt getur reynst að mæla lesskilning í byrjun lestrarnáms sökum pess hve nemendur eru oft stutt á veg komnir í umskráningu. 
Áhrif lestraráhugahvatar á lesskilning liggja međal annars í pví ađ peir sem hafa mikla lestraráhugahvöt lesa yfirleitt meira og fjölbreyttara lesefni en peir sem hafa litla lestraráhugahvöt, og eru einnig líklegri til að lesa í frítíma sínum (Becker, McElvany og Kortenbruck, 2010; Guthrie, Wigfield, Metsala og Cox, 1999; Wang og Guthrie, 2004). Wigfield og Guthrie (1997) sýndu til dæmis fram á að nemendur í 4. og 5. bekk með mikla lestraráhugahvöt lesa nærri prisvar sinnum meira en nemendur með minni lestraráhugahvöt. Svipađar niðurstöður fengust í rannsókn Bakers og Wigfields (1999) sem sýndu fram á að lestrarmagn nemenda í 5. og 6. bekk réđst af pví hvort lestraráhugahvöt peirra var mikil eđa lítil. Lestraráhugahvöt og jákvætt viđhorf til lestrar virđist svo minnka eftir pví sem líđur á grunnskólann (McKenna o.fl., 1995; Wigfield o.fl., 1997). Leiđa má líkum að pví að ef áhugahvöt minnkar og viðhorf til lestrar verður neikvæðara, pá versni einnig árangur í lestri. Pví felst mikill ávinningur í pví að halda nemendum að lestri og vekja og viðhalda áhuga peirra pannig að lestur sé páttur í hefðbundnum daglegum venjum peirra.

Mikilvægt er ađ kanna hver tengsl lestraráhugahvatar og lesskilnings eru međal íslenskra nemenda, en rannsóknir á pessu hefur skort. Markmið pessarar rannsóknar er að leitast við að bæta úr pví og kanna hvort tengsl eru milli pessara mikilvægu pátta í lestrarnámi barna.

\section{Áhugahvöt og kynjamunur í lestri}

Rannsóknir á lestri íslenskra nemenda sýna fram á kynjamun. Drengir lesa minna en stúlkur (Brynhildur Pórarinsdóttir og Póroddur Bjarnason, 2010), fá lægri einkunnir í íslensku á samræmdum prófum og færni peirra í lesskilningi er slakari (Almar M. Halldórsson, 2011). pótt ekki sé um að ræða sérstöđu íslenskra ungmenna miðað við ađrar pjóđir er munur kynjanna í lesskilningi á Íslandi mikill í samanburđi við önnur lönd OECD (Almar M. Halldórsson o.fl., 2013; Almar M. Halldórsson og Ragnar F. Ólafsson, 2016). Íslensk rannsókn Amalíu Björnsdóttur, Baldurs Kristjánssonar og Barkar Hansen (2008) á námsáhuga barna, m.a. lestri, sýnir einnig að pađ dregur úr námsáhuga pegar líđur á grunnskólann og munur á kynjunum eykst.

Niðurstöđur samanburđarrannsóknar sem gerđ var í 46 löndum á 15 ára unglingum sýna að drengir eru mun slakari í lestri en stúlkur; í öllum löndunum skoruđu stúlkur mun hærra en drengir (Chiu og McBride-Chang, 2006). Pisa-rannsóknir OECD-ríkjanna sýna fram á að hærra skor stúlkna en drengja er tengt lestraránægju (OECD, 2010). Alpjóđlegar rannsóknir sýna að stúlkur lesa meira en drengir (Elley, 1994), pær búa yfir meiri lestraráhugahvöt (Marinak og Gambrell, 2010; Wigfield og Guthrie, 1997), hafa meiri trú á eigin lestrarhæfni (Wigfield o.fl., 1997) og pær njóta lestrar meira en drengir (Guthrie og Greaney, 1991).

Rannsóknir benda einnig til pess ađ áhugahvöt og viðhorf til lestrar skipti mögulega meira máli fyrir gengi drengja í lestri en stúlkna (Logan og Johnston, 2009; Logan og Medford, 2011). Rannsókn Oakhills og Petrides (2007) á níu og tíu ára nemendum sýndi til dæmis að pað skiptir meira máli fyrir drengi en stúlkur að lesa áhugavert efni til að skilja textann. Um tvo upplýsingatexta var að ræđa; annars vegar um köngulær en hins vegar um börn í seinni heimsstyrjöldinni. Allir nemendurnir svöruðu lesskilningsverkefni úr báđum textunum en áttu einnig að segja hvor textinn væri áhugaverđari. Stúlkunum gekk jafn vel með báđa textana en strákunum gekk marktækt betur ađ skilja köngulóartextann, 
sem peir höfðu flestir meiri áhuga á (Oakhill og Petrides, 2007). Vísbendingar eru um að pessi munur á lestraráhuga og lesskilningi sé til stađar hjá yngri nemendum en áđur hefur verið talið. Cartwright og samstarfsmenn (2015) fundu til að mynda mun á lestraráhugahvöt og lesskilningi kynjanna strax í fyrstu bekkjum grunnskóla. Stelpum gekk mun betur í lesskilningi og sögðust pær hafa meiri áhuga á lestri. Telja pau að áhugaskortur drengja leiði til minnkandi lestrar og pannig minnkandi lesskilnings og par með aukist kynjamunurinn á árangri í lesskilningi.

Ljóst er ađ margt býr ađ baki lestraráhugahvöt og gengi i lestrartengdum athöfnum eins og lesskilningi. Trú á eigin getu, fyrirmyndir, sjálfstraust og svokölluð snjóboltaáhrif, sem verða við aukinn lestur, geta skipt sköpum. Pannig komust Marinak og Gambrell (2010) að pví að drengir og stúlkur í 3. bekk höfðu jafn mikið sjálfstraust í lestri en drengirnir töldu lesturinn skipta minna máli en stúlkurnar. Trú drengja á eigin hæfni og áhugahvöt hefur mikil áhrif á pað hversu mikið peir leggja á sig við lestur (Logan og Medford, 2011). Skorti pá trú á eigin getu og lestraráhugahvöt getur pađ orđið til pess ađ peir leggja minna á sig í lestrarnáminu. Meginmarkmið rannsóknarinnar er að kanna hvort raunveruleg tengsl séu á milli lestraráhugahvatar og lesskilnings međal íslenskra nemenda í 5. og 6. bekk eins og alpjóđlegar rannsóknir sýna.

\section{Markmið rannsóknarinnar og rannsóknarspurningar}

pær rannsóknir sem hér hefur verið vísað til sýna að tengsl áhugahvatar og lesskilnings eru fyrir hendi. pær benda eindregið til mikilvægis áhugahvatar í öllu námi barna pó peim beri ekki saman um hvort tengslin séu ólík milli kynjanna. Pessi pekking byggist pó ađallega á erlendum rannsóknum, en pekkingu skortir á tengslum áhugahvatar og læsis međal íslenskra barna og ungmenna. PISA-rannsóknin á nemendum 9. bekkjar 2009 leiddi í ljós að sá matspáttur sem sterkast tengdist lesskilningi var ánægja af lestri (Almar M. Halldórsson, 2011). Pessari rannsókn er ætlađ að bæta úr eyđunni í pekkingu á tengslum áhugahvatar og lesskilnings međal íslenskra nemenda á miđstigi grunnskóla.

Rannsóknin sem hér um ræđir er hluti af langtímarannsókn á sjálfstjórnun barna á miđstigi og tengslum hennar við farsælan proska og námsgengi. Sá hluti rannsóknarinnar sem skýrt er frá í pessari grein snýr ađ lestraráhugahvöt og tengslum hennar við lesskilning. Ekki lá fyrir mælitæki um áhugahvöt á íslensku við upphaf rannsóknarinnar og pví var ákveðið að nota nýlegt bandarískt mælitæki Hamiltons og félaga (2013). Eftirfarandi rannsóknarspurningar eru hér lagđar til grundvallar:

1. Hvernig birtist lestraráhugahvöt íslenskra nemenda í 5. og 6. bekk og breytist hún á milli ára? pessari spurningu verđur svarað međ pví að kanna og bera saman međaltöl nemenda á ólíkum undirpáttum áhugahvatar á hvorum tímapunkti fyrir sig og skođa hvort og hvernig pau breytast milli ára.

2. Hver er munur á međaltölum fyrir ólíka undirpætti lestraráhughvatar stúlkna og drengja í 5. og 6. bekk?

3. Spáir lestraráhugahvöt í 5. bekk fyrir um gengi í lesskilningi í 6. bekk? 


\section{AĐFERĐ}

Rannsóknin var langtímarannsókn par sem sömu nemendum var fylgt eftir í tvö ár. Mælingar fóru fram međ 12 mánađa millibili, fyrst pegar nemendur voru í 5. bekk og aftur pegar peir voru í 6 . bekk. Gögnin sem notuð eru í rannsókninni sem er til umfjöllunar hér eru hluti gagna úr stærri rannsókn á miđstigi grunnskóla og takmarkast við fyrstu tvær mælingarnar, pegar nemendur voru í 5. og 6. bekk.

\section{Pátttakendur}

Pátttakendur í rannsókninni voru nemendur fæddir 2004 og var peim fylgt eftir í 5. og 6. bekk. Tekið var klasaúrtak (Cochran, 2007; Lohr, 2009) úr peim skólum á höfuđborgarsvæðinu og Reykjanesi sem voru međ fleiri en einn bekk (fleiri en 30 nemendur í árgangi). Átta skólar lentu í úrtakinu og í peim voru skráđir 503 nemendur í 24 bekkjum. Foreldrar 400 nemenda gáfu sampykki fyrir rannsókninni eđa 79,5\%. Stúlkur voru 221 (55,2\%) og drengir voru 179 (44,8\%). Međalaldur bátttakenda við fyrri fyrirlögn (í 5. bekk) var 10,7 ár (sf $=0,3$ ) og 11,7 við seinni fyrirlögn (í 6. bekk).

\section{Mælitæki}

Til að meta lestraráhugahvöt nemenda var spurningalisti Hamiltons og félaga (2013) (e. reading motivational orientation scales) lagđur fyrir nemendur í 5. bekk (sjá viđauka). Til að meta lesskilning var lesskilningsmæling Menntamálastofnunar (Karl Fannar Gunnarsson og Sigurgrímur Skúlason, 2009) lögð fyrir nemendur í 5. og 6. bekk. Til að meta magn lestrar nemenda í 6 . bekk svöruđu nemendur einnig mælingu á lestrarmagni og var sú spurning fengin úr PISA-könnun frá árinu 2000. Til ađ fá fram réttmætismælingu á áhugahvatarkvarđanum svöruðu nemendur í 5. bekk einnig spurningalista Banduras (2006) um trú á eigin getu til sjálfstjórnunar í námi (e. self-efficacy for self-regulated learning).

\section{Lestraráhugahvöt}

Mælitækið, sem mælir afstöđu til lestrarframmistöðu, byggist á kenningu Nicholls (1989) um frammistöðumarkmið (e. achievement goal theory) par sem gert er ráð fyrir annars vegar verkefnamiðađri og hins vegar sjálfmiðađri frammistöðu. Mælitækið er byggt á 18 spurningum sem falla undir fjórar víddir frammistöđu; lestraráhuga (e. reading interest), lestrarleikni (e. reading mastery), lestrarsjálf (e. reading ego) og lestrarfælni (e. reading work avoidance). Lestraráhugi og lestrarleikni byggjast á verkefnamiðađri frammistöđu en lestrarsjálf og lestrarfælni byggjast á sjálfmiðađri frammistöđu. Hver spurning innihélt fjóra svarmöguleika á Likert-kvarđa; mjög ósammála, frekar ósammála, frekar sammála eđa mjög sammála.

Langtímarannsókn Hamiltons og félaga (2013) á mælitækinu sýndi fram á hugtakaréttmæti og áreiđanleika hjá sex mismunandi aldurshópum fyrir alla fjóra undirpættina (áreiðanleikastuðullinn fyrir 5. bekk var $\alpha=0,79-0,87$ og í 6 . bekk $\alpha=0,74-0,84$ ). Eftir pýđingu var spurningalistinn bakpýddur og minni háttar breytingar gerđar á orđalagi. Listinn var forprófađur á 30 nemendum í 5. bekk sem ekki lentu í úrtaki rannsóknarinnar. Að lokinni forprófun voru gerđar lítils háttar breytingar á býđingu til ađ gera orđalag skýrara en ekki var um efnislegar breytingar að ræða. 


\section{Lesskilningur}

Lesskilningsmælingin Orđskilningur frá Menntamálastofnun (Karl Fannar Gunnarsson og Sigurgrímur Skúlason, 2009) var lögð fyrir til ađ meta lesskilning nemenda. Prófið er byggt á samræmdum prófum í íslensku og var forprófað og staðlað með 900 nemenda úrtaki í 4. til 7. bekk og reyndist innri áreiðanleiki pess viðunandi eđa $\alpha=0,79$ (Karl Fannar Gunnarsson og Sigurgrímur Skúlason, 2009). Prófið er byggt á fjölvalsspurningum úr tveimur mismunandi textategundum sem henta fyrir fyrirlagnir í hóp í 4. til 5. bekk. Fyrri textinn var frásagnartexti og seinni textinn upplýsingatexti og svöruđu nemendur tíu spurningum úr hvorum texta. Allar spurningarnar voru krossaspurningar međ premur valmöguleikum.

\section{Trú á eigin getu og lestrarmagn}

Til pess ađ kanna samleitniréttmæti kvarđans sem metur lestraráhugahvöt var fylgni hvers undirpáttar við tvö kenningarlega skyld mælitæki könnuð. Fyrra mælitækið er spurningalisti byggður á mælingu Banduras (1986) á trú nemenda á eigin getu til sjálfstjórnunar í námi. Mælitækið inniheldur sex spurningar sem nemendur svara á fimm punkta Likertkvarđa. Sýnt hefur veriđ fram á réttmæti og innri stöđugleika kvarđans (Elsa Lyng Magnúsdóttir, Steinunn Gestsdóttir og Kristján Ketill Stefánsson 2013; Usher og Pajares, 2006; Zimmerman og Martinez-Pons, 1988). Innri áreiðanleiki í íslensku rannsókninni var góđur (Cronbach's alfa=0,89) (Elsa Lyng Magnúsdóttir o.fl., 2013). Seinna mælitækið var spurning um lestrarmagn („,hversu miklum tíma verđu í lestur pér til gamans á hverjum degi?“), fengin úr PISA-könnuninni frá árinu 2000 (Almar M. Halldórsson, 2006). Svarmöguleikarnir voru fimm; „ég les mér ekki til gamans“, „30 mínútum eđa minna á hverjum degi“, „meira en 30 mínútum til minna en 60 mínútum á hverjum degi“, „1 til 2 klukkustundum á dag“ og „meira en 2 klukkustundum á dag“.

\section{Framkvæmd}

Haft var samband við skólayfirvöld í öllum sveitarfélögum á höfuðborgarsvæðinu og Reykjanesi og óskað eftir leyfi til að hafa samband við skólastjóra grunnskólanna vegna pátttöku í rannsókninni. Pegar klasaúrtak hafđi verið tekið var haft samband við skólastjóra í viðkomandi skólum par sem rannsóknin var kynnt og leyfi fengið til að óska eftir pátttöku allra umsjónarkennara og nemenda í 5. bekk og foreldra peirra í rannsókninni. Átta af prettán grunnskólum sampykktu pátttöku, međ samtals 503 nemendur fædda 2004, sem var talið viðunandi fjöldi. Upplýsinga- og kynningabréf ásamt sampykkisbréfi var sent heim til allra nemenda í 5 . bekk pegar kennarar höfðu sampykkt pátttöku. Kennarar sáu um dreifingu peirra og að safna saman peim bréfum sem innihéldu upplýst sampykki. Lokaítrekun var komið símleiðis til peirra sem ekki höfðu tekið afstöðu, skömmu fyrir fyrirlögn, og sampykki fengið. Fyrri gagnasöfnun fór fram vorið 2015 og sú seinni 12 mánuđum síđar. Fyrirlögn var á skólatíma á peim tíma sem hentađi kennurum. Rannsakendur fóru í skólana tveir saman og lögđu fyrir heila bekki til ađ trufla skólastarf sem minnst. Allir nemendur leystu lesskilningsverkefni og svöruðu spurningalista um lestraráhugahvöt, lestrarmagn og trú á eigin lestrargetu. 


\section{Tölfræòileg úrvinnsla}

Tölfræđiforritið SPSS (útgáfa 24) var notað við úrvinnslu gagna. Lýsandi tölfræđi fyrir úrtakið var sett fram til að svara rannsóknarspurningum og fylgni (Pearson) mæld með til að kanna réttmæti. Forsendur ađhvarfsgreiningar voru kannađar, fylgni milli frumbreyta, VIF og Klien's Rule, og voru forsendur fullnægjandi. Tengsl lestraráhugahvatar við lesskilning voru einnig skoðuð með ađhvarfsgreiningu í SPSS.

\section{NIĐURSTÖĐUR}

Hér á eftir verđa niðurstöđur rannsóknarinnar kynntar. Fyrst verđa próffræđilegir eiginleikar mælitækisins um lestraráhugahvöt metnir. Pví næst verđa međaltöl nemenda á ólíkum undirpáttum áhugahvatar á hvorum tímapunkti fyrir sig skođuð og borin saman (rannsóknarspurning 1) og kannađ hvort pau séu ólík eftir kyni (rannsóknarspurning 2). Að lokum verður svo greint frá niðurstöđum aðhvarfsgreiningar sem metur hvort lestraráhugahvöt í 5. bekk spáir fyrir um gengi í lesskilningi ári síđar, eđa i 6. bekk (rannsóknarspurning 3).

\section{Próffræơilegir eiginleikar mælingar á lestraráhugahvöt}

Til að meta innri stöđugleika mælitækisins um lestraráhugahvöt var fylgni á milli allra atriða innan hvers undirpáttar metin með Cronbach's Alpha (tafla 1).

Tafla 1. Innri stöđugleiki undirbátta lestraráhugahvatar í 5. bekk

\begin{tabular}{|l|l|l|}
\hline & Cronbach's alpha & Stöđugleiki \\
\hline Lestraráhugi & 0,88 & Mjög góđur \\
\hline Lestrarleikni & 0,82 & Mjög góđur \\
\hline Lestrarsjálf & 0,78 & Góđur \\
\hline Lestrarfælni & 0,77 & Góđur \\
\hline
\end{tabular}

Lestraráhugi var mældur með fimm spurningum (t.d. „,mér líđur best pegar ég les um eitthvað mjög áhugavert“) og var innri stöđugleiki pess kvarða viðunandi $(\alpha=0,88)$. Fjórar spurningar meta undirpáttinn lestrarleikni (t.d. „mér líđur best ef ég get lesið lengri og erfiðari bækur en ég gat áđur lesið“) og var fylgni milli atriða peirra spurninga sem mæla páttinn einnig viðunandi: $\alpha=0,82$. priđji kvarđinn, lestrarsjálf, samanstóð af fimm spurningum (t.d. „mér líđur best ef ég fæ eina af hæstu einkunnum í bekknum“) og innri áreiðanleiki pess páttar var ađeins lægri $(\alpha=0,78)$. Sama má segja um páttinn sem metur lestrarfælni eđa hvort nemendur forđast lestur, en fjórar spurningar falla undir hann (t.d. „mér líđur best ef ég les bara smávegis og kemst upp með pað“). Innri stöðugleiki pess páttar var $\alpha=0,77$.

Til að skođa samleitniréttmæti mælitækisins um lestraráhugahvöt var fylgni hvers undirpáttar við tvö hugtakalega skyld mælitæki könnuð; aðlagað mælitæki Banduras (1986) um trú á eigin getu til sjálfstjórnunar í námi sem lagt var fyrir í 5. bekk (sjá töflu 2) og mat 
á pví hversu oft nemendur lesa í frístundum sínum (lestrarmagn) (OECD, 2010) sem lagt var fyrir í 6 . bekk (sjá töflu 3). Eins og sjá má var nokkuð mikil jákvæđ fylgni á milli trúar á eigin lestrargetu og flestra undirpátta lestraráhugahvatar ( $r=0,58$ fyrir lestraráhuga, $r=0,63$ fyrir lestrarleikni og $r=0,47$ fyrir lestrarsjálf), en eins og búast mátti við var neikvæð fylgni á milli lestrarfælni og trúar á eigin lestrargetu $(r=-0,39)$. Heldur minni fylgni var á milli undirbátta lestraráhugahvatar og lestrarmagns í 6. bekk (sjá töflu 3), en hún var $r=0,36$ við lestraráhuga, $r=0,32$ við lestrarleikni, $r=0,22$ við lestrarsjálf. Aftur á mót kom fram nokkuð sterk neikvæð fylgni milli lestrarmagns og lestrarfælni $r=-0,47$. Framangreindar niðurstöður gefa til kynna að mælitækið hafi til að bera viðunandi áreiðanleika og réttmæti og var pað pví notað við áframhaldandi greiningu gagnanna.

Tafla 2. Fylgni milli undirbátta lestraráhugahvatar og trúar á eigin lestrargetu í 5 . bekk

\begin{tabular}{|l|l|l|l|l|l|}
\hline & Lestraráhugi & Lestrarleikni & Lestrarsjálf & Lestrarfælni & $\begin{array}{l}\text { Trú á eigin } \\
\text { lestrargetu }\end{array}$ \\
\hline Lestraráhugi & 1 & & & & \\
\hline Lestrarleikni &, $64^{* *}$ & 1 & & & \\
\hline Lestrarsjálf & $56^{* *}$ & $56^{* *}$ & 1 & & \\
\hline Lestrarfælni &,$- 26^{* *}$ &,$- 35^{* *}$ &,- 10 & 1 & \\
\hline Trú á eigin lestrargetu &, $58^{* *}$ &, $63^{*}$ &, $47^{* *}$ &,$- 39^{* *}$ & 1 \\
\hline
\end{tabular}

$* * p<0,01$

$* p<0,05$

Tafla 3. Fylgni milli undirbátta lestraráhugahvatar og lestrarmagns í 6. bekk

\begin{tabular}{|l|l|l|l|l|l|}
\hline & Lestraráhugi & Lestrarleikni & Lestrarsjálf & Lestrarfælni & Lestrarmagn \\
\hline Lestraráhugi & 1 & & & & \\
\hline Lestrarleikni &, $56^{* *}$ & 1 & & & \\
\hline Lestrarsjálf &, $38^{*}$ &, $45^{* *}$ & 1 & & \\
\hline Lestrarfælni &,$- 38^{* *}$ &,$- 42^{* *}$ &,- 04 & 1 & \\
\hline Lestrarmagn &, $36^{* *}$ &, $32^{* *}$ &, $22^{* *}$ &,$- 47^{* *}$ & 1 \\
\hline
\end{tabular}

$* * p<0,01$

$* p<0,05$

\section{Lestraráhugahvöt meðal íslenskra barna í 5. og 6. bekk}

Markmið rannsóknarinnar var að kanna hvernig lestraráhugahvöt birtist í 5. og 6. bekk međal íslenskra nemenda og hvernig hún breytist milli ára og og mögulegan kynjamun par á. Einnig að kanna hvort um tengsl milli lestraráhugahvatar og lesskilnings sé að ræða. Til pess að svara pessu voru međaltöl nemenda fyrir undirpættina fjóra skoðuð og borin saman í 5 . og 6 . bekk. Hver undirpáttur var mældur með fjórum til fimm 
fullyrđingum. Undirpátturinn lestraráhugi var mældur með eftirfarandi fullyrðingum: Mér líđur best pegar ég ... 1) les um eitthvađ mjög áhugavert, 2) les sögu eđa bók sem ég hef virkilega gaman af, 3) les mína uppáhalds tegund af bók, 4) hef mikinn áhuga á bví sem ég les og 5) les eitthvađ sem er mjög spennandi. Lestrarleikni var mæld með fjórum fullyrđingum en pær eru: Mér líđur best ef ég ... 1) get lesið lengri og erfiðari bækur en ég gat áđur lesið, 2) get lesið eitthvað erfitt með pví að leggja hart að mér, 3) skil að lokum mjög flókna hugmynd og 4) get lesið eitthvað erfitt og skilið pað. Undirpátturinn lestrarsjálf var mældur með eftirfarandi fullyrđingum: Mér liđur best ef ... 1) ég fæ eina af hæstu einkunnunum í bekknum, 2) ég sýni fólki ađ ég er klár, 3) ég sýni fólki ađ ég sé góđur lesandi, 4) enginn bendir á villur sem ég geri í lestri og 5) ég get lesið pyngri bækur en ađrir nemendur. Lestrarfælni var mæld með fjórum fullyrđingum sem eru: Mér líđur best ef ... 1) ég get hangsað í stað pess að lesa, 2) ég les bara smávegis og kemst upp með pað, 3) ég parf ekki að gera neina heimavinnu í lestri og 4) allur lestur er auðveldur (sjá einnig viðauka).

Niðurstöðurnar eru teknar saman í töflu 4. Eins og fram kemur var međaltalið hjá nemendum í 5. bekk hæst fyrir undirpáttinn lestraráhuga eđa 3,48 stig af 4 mögulegum fyrir hverja fullyrđingu, en ađeins lægra fyrir lestrarleikni (3,16 af 4 mögulegum) og lestrarsjálf (3,09 af 4 mögulegum). Međaltalið fyrir undirbátturinn lestrarfælni var svo 2,16 stig af 4 mögulegum fyrir hverja spurningu. Svipað mynstur kom fram hjá nemendum ári síđar eđa í 6. bekk. Par var međaltalið einnig hæst fyrir undirbáttinn lestraráhuga eđa að međaltali 3,54 stig fyrir hverja fullyrđingu. Međaltal fyrir undirpáttinn lestrarleikni var 3,20 stig og 3,07 stig fyrir lestrarsjálf. Aftur var međaltalið lægst fyrir lestrarfælni, eđa 2,25 stig. Pessar niðurstöður gefa til kynna að stærstur hluti áhugahvatar hjá nemendum í 5. og 6. bekk ráđist fyrst og fremst af mikilvægi pess að bæta lestrarfærni sína og pví hversu áhugavert lesefnið er.

Lestraráhugahvöt nemenda var nokkuð stöđug milli 5. og 6. bekkjar. Undirpátturinn lestraráhugi jókst úr 3,48 stigum í 3,54 stig að međaltali, lestrarleikni jókst lítillega eđa úr 3,16 i 3,20 stig ađ međaltali, og lestrarsjálf stendur nánast í stađ (úr 3,09 í 3,07 stig að međaltali). Pessar breytingar á međaltölum voru pó ekki tölfræđilega marktækar. Lestrarfælni jókst aftur á móti marktækt úr 2,16 stigum að međaltali i 2,25 stig ( $t=-2,59, p<0,01)$.

Tafla 4. Međaltöl fyrir undirbætti lestraráhugahvatar og lesskilning í 5. og 6. bekk

\begin{tabular}{|l|r|r|r|r|}
\hline & $\begin{array}{r}\text { Međaltal } \\
\text { 5. bekkur }\end{array}$ & \multicolumn{1}{|c|}{$\begin{array}{c}\text { Stađalfrávik } \\
\text { 5. bekkur }\end{array}$} & $\begin{array}{l}\text { Međaltal } \\
\text { 6. bekkur }\end{array}$ & $\begin{array}{r}\text { Stađalfrávik } \\
\text { 6. bekkur }\end{array}$ \\
\hline $\begin{array}{l}\text { Lestraráhugahvöt }- \\
\text { lestraráhugi }\end{array}$ & $\begin{array}{r}3,48 \\
(\mathrm{~N}=383)\end{array}$ & 0,62 & $\begin{array}{r}3,54 \\
(\mathrm{~N}=386)\end{array}$ & 0,55 \\
\hline $\begin{array}{l}\text { Lestraráhugahvöt }- \\
\text { lestrarleikni }\end{array}$ & $\begin{array}{r}3,16 \\
(\mathrm{~N}=375)\end{array}$ & 0,71 & $\begin{array}{r}3,20 \\
(\mathrm{~N}=380)\end{array}$ & 0,68 \\
\hline $\begin{array}{l}\text { Lestraráhughvöt - } \\
\text { lestrarsjálf }\end{array}$ & $\begin{array}{r}3,09 \\
(\mathrm{~N}=368)\end{array}$ & 0,68 & $\begin{array}{r}3,07 \\
(\mathrm{~N}=378)\end{array}$ & 0,62 \\
\hline $\begin{array}{l}\text { Lestraráhugahvöt }- \\
\text { lestrarfælni }\end{array}$ & $\begin{array}{r}2,16 \\
(\mathrm{~N}=372)\end{array}$ & 0,81 & $(\mathrm{~N}=377)$ & 0,80 \\
\hline $\begin{array}{l}13,43 \\
\text { Lesskilningur }\end{array}$ & $(\mathrm{N}=381)$ & 3,55 & $\begin{array}{r}14,92 \\
(\mathrm{~N}=390)\end{array}$ & 3,44 \\
\hline
\end{tabular}




\section{Er kynjamunur á lestraráhugahvöt í 5. og 6. bekk?}

Einnig var skođað hvort kynjamunur væri á lestraráhugahvöt með pví ađ bera saman mun á međaltölum undirpátta eftir kyni. Niðurstöđurnar leiddu í ljós marktækan kynjamun stúlkum í vil á tveimur af fjórum undirpáttum í 5. bekk. Peir voru lestraráhugi ( $M=3,59$ stig fyrir stúlkur og $M=3,35$ fyrir drengi, $t=-3,817, p<0,01$ ) og lestrarleikni ( $M=3,23$ fyrir stúlkur og $M=3,07$ fyrir drengi, $t=-2,244, p<0,05)$. Stúlkurnar mældust einnig međ fleiri stig en drengir á undirbættinum lestrarsjálf (3,12 stig fyrir stúlkur og 3,04 stig fyrir drengi), en sá munur reyndist ekki vera tölfræđilega marktækur. Pá mældust drengirnir ađ međaltali međ fleiri stig á undirkvarđanum lestrarfælni eđa 2,39 stig, en stúlkurnar 1,97 stig og reyndist sá munur marktækur $(t=5,187, p<0,01)$. Nánast sama mynstur kom fram í 6 . bekk. Međaltal stúlknanna á undirpættinum lestraráhugi var 3,65 stig en 3,41 stig á međal drengjanna, og var munurinn tölfræđilega marktækur $(t=-4,319, p<0,01)$. Hið sama gilti um undirkvarðann lestrarleikni $(t=-4,251, p<0,05)$ par sem međaltal stúlkna var 3,33 stig en drengja 3,04 stig. Líkt og í 5. bekk reyndist ekki vera tölfræđilega marktækur munur á međaltölum stúlkna $(M=3,09)$ og drengja $(M=3,04)$ fyrir undirpáttinn lestrarsjálf. pá mældust drengirnir ađ međaltali međ fleiri stig á undirkvarđanum lestrarfælni eđa 2,49 stig en stúlkurnar 2,07 stig og reyndist sá munur marktækur $(t=5,245, p<0,01)$.

\section{Spáir lestraráhugahvöt í 5. bekk fyrir um gengi í lesskilningi î 6. bekk?}

Lesskilningur nemenda var einnig metinn í 5. og 6. bekk. Í pví skyni svöruđu nemendur 20 lesskilningsspurningum eftir lestur texta, par sem hvert rétt svar gaf 1 stig og gátu stigin pví verið á bilinu 0-20. Međaltal stiga og stađalfrávik má sjá í töflu 4. Par kemur fram ađ međaltal stiga í 5 . bekk var 13,43 (SD=3,55, N=381). Sú tala hækkađi ađeins á milli ára, eđa upp í 14,92 stig ( $S D=3,44, N=390)$. Pegar dreifing svara á lesskilningsprófinu var könnuð eftir kyni (tafla 5) kom í ljós að í 5. bekk fengu stúlkurnar að međaltali 13,74 stig og drengirnir 13,04 stig, en munurinn reyndist ekki vera marktækur. í 6. bekk virtist bilið á milli stúlkna og drengja pó heldur breikka og reyndist pá munurinn vera tölfræđilega marktækur ( $t=-4,090, p<0,01)$ (sjá töflu 5).

Til að kanna tengs I milli lestraráhugahvatar í 5. bekk og lesskilnings í 6 . bekk var reiknuð fylgni (Pearson) við alla undirpættina (sjá töflu 6). Veik en marktæk fylgni mældist milli lestraráhuga og lesskilnings $(r=0,22, p<0,01)$ og á milli lestrarleikni og lesskilnings $(r=0,28 p,<0,01)$. Aftur á móti reyndist ekki vera marktæk fylgni á milli lestrarsjálfs og lesskilnings. Neikvæð marktæk fylgni var á milli lestrarfælni og lesskilnings $(r=-0,31, p<$ 0,01). Pessar niðurstöđur voru í takt við væntingar okkar og í samræmi við niðurstöđur Hamiltons og félaga (2013) sem einnig fundu fylgni milli lestrarleikni og lesskilnings og neikvæða fylgni milli lestrarfælni og útkomu á lesskilningsprófi.

Til pess að kanna hvort lestraráhugahvöt spáir fyrir um framfarir í lesskilningi á milli 5. og 6. bekkjar var kannað hvort lestraráhugahvöt í 5. bekk skýrđi getu í lesskilningi í 6. bekk, umfram skýringu lesskilnings i 5 . bekk. Eins og sjá má í töflu 7 skýrđi lesskilningur í fimmta bekk 36\% af dreifingu einkunna í lesskilningi ári síđar, og reyndist lestraráhugahvöt í 5 . bekk bæta 5\% við pá skýringu. Pađ pýđir ađ lestraráhugahvöt skýrir 5\% í framförum á pessu tiltekna prófi í lesskilningi á milli ára, umfram fyrri frammistöđu í lesskilningi. 
Tafla 5. Munur á međaltölum lestraráhugahvatar og lesskilnings í 5. og 6. bekk eftir kyni

\begin{tabular}{|l|c|c|c|c|c|c|}
\hline & \multicolumn{3}{|c|}{5. bekkur } & \multicolumn{3}{c|}{ 6. bekkur } \\
\hline & Drengir & Stúlkur & t-gildi & Drengir & Stúlkur & t-gildi \\
\hline Lestraráhugi & 3,35 & 3,59 & $-3,817^{* *}$ & 3,41 & 3,65 & $-4,319 * *$ \\
\hline Lestrarleikni & 3,07 & 3,23 & $-2,244^{*}$ & 3,04 & 3,33 & $-4,251^{* *}$ \\
\hline Lestrarsjálf & 3,04 & 3,12 & $-1,126$ & 3,04 & 3,09 & $-0,799$ \\
\hline Lestrarfælni & 2,39 & 1,97 & $5,187^{* *}$ & 2,49 & 2,07 & $5,245^{* *}$ \\
\hline Lesskilningur & 13,04 & 13,74 & $-1,952$ & 14,13 & 15,54 & $-4,090^{* *}$ \\
\hline
\end{tabular}

$* * p<0,01$

$* p<0,05$

Tafla 6. Fylgni ( $r$ ) lestraráhugahvatar í 5. bekk og lesskilnings í 6. bekk

\begin{tabular}{|l|c|c|c|c|c|}
\hline & $\begin{array}{c}\text { Lestrar- } \\
\text { áhugi 5. b. }\end{array}$ & $\begin{array}{c}\text { Lestrar- } \\
\text { leikni 5. b. }\end{array}$ & $\begin{array}{c}\text { Lestrar- } \\
\text { sjálf 5. b. }\end{array}$ & $\begin{array}{c}\text { Lestrar- } \\
\text { fælni 5. b. }\end{array}$ & $\begin{array}{c}\text { Lesskilningur } \\
6 . \mathrm{b} .\end{array}$ \\
\hline Lestraráhugi 5. b. & 1 & & & & \\
\hline Lestrarleikni 5. b. &, $64^{* *}$ & 1 & & & \\
\hline Lestrarsjálf 5. b. &, $56^{* *}$ &, $56^{* *}$ & 1 & & \\
\hline Lestrarfælni 5. b. &,$- 26^{* *}$ &,$- 35^{* *}$ &,- 10 & 1 & \\
\hline Lesskilningur 6. b. &, $22^{* *}$ &, $28^{* *}$ &, 09 &,$- 31^{* *}$ & 1 \\
\hline
\end{tabular}

** $p<0,01$

Tafla 7. Niðurstöður línulegrar aðhvarfsgreiningar á tengslum lestraráhugahvatar í 5. bekk við lesskilning í 6. bekk ( $\mathrm{N}=332$ )

\begin{tabular}{|l|c|c|c|c|c|c|c|}
\hline Breytur & & & & & & & \\
\hline & $B$ & St. $B$ & $\beta$ & $\mathrm{R}^{2}$ & $\Delta \mathrm{R}^{2}$ & $F$ fyrir $\Delta \mathrm{R}^{2}$ & $p$ fyrir $\mathrm{F}$ \\
\hline Módel 1 & & & & & & & \\
\hline Lesskilningur 5. b. & 0,60 & 0,04 & 0,60 & 0,36 & 0,36 & 187,09 & 0,00 \\
\hline & & & & & & & \\
\hline Módel 2 & & & & 0,41 & 0,05 & 6,75 & 0,00 \\
\hline Lesskilningur 5. b. & 0,54 & 0,04 & $0,54^{* *}$ & & & & \\
\hline Lestraráhugi 5. b. & 0,06 & 0,06 & 0,05 & & & & \\
\hline Lestrarleikni 5. b. & 0,10 & 0,07 & 0,08 & & & & \\
\hline Lestrarsjálf 5. b. & $-0,06$ & 0,05 & $-0,06$ & & & & \\
\hline Lestrarfælni 5. b. & $-0,18$ & 0,05 & $-0,18^{* *}$ & & & & \\
\hline
\end{tabular}

$* * p<0,01$ 


\section{UMRÆEA}

Fjöldi rannsókna hefur sýnt að lestraráhugahvöt gegnir mikilvægu hlutverki í lesskilningi nemenda á ólíkum aldri. Fáar rannsóknir hafa pó verið gerđar á lestraráhugahvöt međal íslenskra grunnskólanemenda og peim áhrifum sem hún hefur á lesskilning peirra. Megintilgangur pessarar rannsóknar var að skođa hvernig lestraráhugahvöt birtist međal íslenskra nemenda í 5. bekk og 6 . bekk, próun hennar milli ára og mögulegan kynjamun par á. Einnig var kannađ hvort lestraráhugahvöt í 5.bekk spáir fyrir um gengi í lesskilningi ári síđar.

\section{Birting lestraráhugahvatar og próun hennar}

Niðurstöđur pessarar rannsóknar gefa til kynna ađ stærstan hluta lestraráhugahvatar á miðstigi megi rekja til markmiða sem tengjast verkefnisbundinni frammistöđu (e. task orientation/mastery goal orientation) (Ames, 1992; Elliott og Dweck, 1988; Nicholls, 1984, 1989), en međaltöl bæđi stúlkna og drengja í 5. og 6. bekk voru hæst á peim undirpáttum lestraráhugahvatar sem tengjast markmiðum um lestrarleikni og áhuga á lesefninu. pađ má pví segja að verkefnamiðuð afstađa til náms skipti máli fyrir gengi nemenda í námi og pví er mikilvægt fyrir kennara að leggja áherslu á pá pætti sem ýta undir verkefnamiðađa afstöđu. Fyrir pessa afstöđu gildir að nemandi ber árangur sinn saman við fyrri árangur og eigin framfarir og leggur sig fram um að gera sitt besta.

Frammistöðumarkmið sem byggjast á sjálfmiðađri afstöđu (e. ego orientation/performance orientation) (Ames, 1992; Elliott og Dweck, 1988; Nicholls, 1984, 1989) virðast aftur á móti ekki vera eins mikilvægur hluti lestraráhugahvatar hjá nemendum á pessum aldri, en međaltöl voru lægri fyrir pá tvo undirpætti sem falla undir slíka afstöđu, lestrarsjálf og lestrarfælni (Hamilton o.fl., 2013). Petta pýđir að sjálfmiðuð afstađa til náms skiptir ekki eins mikli máli fyrir gengi nemenda í námi. Ađ bera sig saman við ađra og keppast við að gera betur en ađrir er pví ekki til pess fallið að standa sig betur í námi. Svipað mynstur kom fram í rannsókn Hamiltons og félaga (2013) par sem međaltal undirpáttarins lestraráhuga var hæst, næsthæst var međaltal undirpáttanna lestrarleikni og lestrarsjálfs og lægst međaltal fyrir undirpáttinn lestrarfælni. Hér er pví um að ræđa mikilvæga viðbót við pá pekkingu ađ verkefnamiðuð frammistađa sé sú frammistađa sem skiptir máli í lestraráhugahvöt nemenda. Sú áhersla sem hefur veriđ ríkjandi í íslenskum skólum á ađ nemendur taki ábyrgð á eigin námi og setji sér markmið (Mennta- og menningarmálaráđuneyti, 2012) ætti pví ađ vera til pess fallin ađ styđja árangur nemenda í námi.

Niðurstöđur rannsóknarinnar benda jafnframt til pess að lestraráhugahvöt íslenskra nemenda við upphaf miðstigs sé nokkuð stöđug milli ára, bæđi hjá stúlkum og drengjum. Áhugavert verđur pó ađ fylgjast međ hvort sú próun heldur áfram par sem erlendar rannsóknir sýna ađ talsvert dregur úr lestraráhugahvöt nemenda pegar líđa tekur á miđstigiđ (McKenna o.fl., 1995; Wigfield o.fl., 1997). Ástæđuna má međal annars rekja til aukins samanburđar við jafnaldra og breikkandi bils í getu nemenda (Wigfield o.fl., 1997). Eini undirpátturinn sem jókst á milli ára í pessari rannsókn var lestrarfælni, sem býđir ađ íslenskir nemendur verđa neikvæðari gagnvart lestri og lestrartengdum athöfnum pegar líđur á miðstigið. pessar niðurstöđur eru í samræmi við niðurstöđur rannsóknar Amalíu Björnsdóttur og félaga (2008) á íslenskum grunnskólabörnum, sem sýndu minnkandi námsáhuga (par á međal á lestri) eftir pví sem leiđ á grunnskólann. 
Pegar međaltöl nemenda fyrir undirpætti lestraráhugahvatar í 5. og 6. bekk voru skoðuð eftir kyni kom í ljós að stúlkurnar mátu markmið sem tengjast lestraráhuga og lestrarleikni marktækt meira en drengirnir. Stúlkur virðast pví hafa sterkari markmið sem tengjast verkefnisbundinni frammistöđu í lestri en drengir. Aftur á móti virđast drengir frekar forðast lestur en stúlkur samkvæmt niðurstöđum rannsóknarinnar, bæði í 5. og 6. bekk. Pessar niðurstöđur ríma við fyrri rannsóknir sem sýna að stúlkur mælast með meiri lestraráhugahvöt og forđast lestur síđur en drengir. Margar mögulegar skýringar hafa verið gefnar á kynjamun í lestri og lestraráhuga. Til dæmis hefur verið bent á að mæður séu betri lestrarfyrirmyndir en feđur pví pær lesi meira, hjálpi börnum sínum oftar með heimanámið og lesi frekar fyrir pau (Millard, 1997).

\section{Tengsl lestraráhugahvatar og lesskilnings}

Pegar tengs। hvers undirpáttar lestraráhugahvatar í 5. bekk við lesskilning í 6 . bekk voru skoðuð kom í ljós marktæk fylgni við lestraráhuga og lestrarleikni og neikvæð marktæk fylgni við lestrarfælni. Pessi tengsl héldust marktæk, jafnvel eftir að áhrifum fyrri frammistöđu í lesskilningi var haldið stöđugum. Pessir undirpættir lestraráhugahvatar spá pví ekki aðeins fyrir um stöđu nemenda í lesskilningi, heldur einnig um framfarir. Undirpátturinn lestrarsjálf var aftur á móti ótengdur frammistöđu í lesskilningi ári síđar.

Samkvæmt pessum niđurstöđum ætti að leggja áherslu á verkefnamiðađa nálgun í kennslu en ekki frammistöðumiðaða og er pað í takt við niðurstöđur Hamiltons og félaga (2013). Einnig komu í ljós neikvæð tengsl lestrarfælni og lesskilnings sem segja okkur að pað að forðast lestrartengdar athafnir hafi neikvæð áhrif á lesskilning nemenda ári síðar. Pví parf að vinna að pví að ýta undir lestrarleikni nemenda með pví ađ hvetja pá til að miða árangur í lestri út frá eigin framförum í stađ pess ađ bera sig saman við ađra. Einnig parf að ýta undir lestraráhuga međ pví að sjá til pess að nemendur hafi ađgang að áhugaverðu efni og loks parf að gæta pess að peir forđist ekki lestrartengdar athafnir. pegar tengslin eru skoðuð með línulegri ađhvarfsgreiningu kemur í ljós að marktæk tengsl eru milli lestraráhugahvatar í 5. bekk og gengis á lesskilningsmælingunni i 6 . bekk, jafnvel eftir að áhrifum lesskilnings í 5. bekk var haldið stöđugum. Við getum pví sagt með nokkurri vissu að framfarir nemendanna í lesskilningi frá 5. til 6. bekkjar megi að hluta til rekja til lestraráhugahvatar, ekki ađeins fyrri færni í lesskilningi.

\section{Hagnýtt gildi niðurstaðna}

Pessar niðurstöður gefa tilefni til að skoða hvort hægt sé að auka lesskilning með aukinni áherslu á lestraráhugahvöt, eins og fyrri rannsóknir hafa sýnt (t.d. Guthrie, Wigfield og Perencevich, 2004). Petta parf að kanna betur, en mikilvægt er fyrir kennara og foreldra að vita hvort aukin lestraráhugahvöt skilar betri lesskilningi. Tengsl lestrarleikni og lesskilnings gefa til kynna að nemandinn ætti að leggja áherslu á að bæta sína persónulegu frammistöđu í lestri og auka pannig áhuga sinn í stað pess að bera sig saman við aðra. Einnig sýndu niðurstöðurnar mikilvægi pess að nemendur forðist ekki lestur. Mikilvægt er að kennarar hafi á valdi sínu leiđir til að vekja og viðhalda áhugahvöt nemenda (Linnenbrink og Pintrich, 2002), sér í lagi hvað varðar verkefnamiðađa frammistöđu eins og lestrarleikni og reglulegan lestur. 
peir pættir sem hafa áhrif á áhugahvöt eru annars vegar áreynsla, hæfni og viðleitni, sem einstaklingurinn getur stjórnađ, og hins vegar hæfileikar, heilsa og skap, sem ekki er hægt að stjórna (Pintrich og Schunk, 2002). Með markvissu kennsluskipulagi er hægt að stuðla að mikilli lestraráhugahvöt međal nemenda (Guthrie og Cox, 2001). Með fjölbreyttu úrvali lesefnis, lestrarhvetjandi umhverfi, vali á lesefni, samvinnu nemenda, stuðningi foreldra og vina, lestrarfyrirmyndum og pví að lesa fyrir nemendur er hægt aঠ kveikja og viðhalda lestraráhuga (Gambrell, 1996, 2011; Gambrell, Palmer, Codling og Mazzoni, 1996). Rannsóknir sýna einnig að ýmislegt í umhverfinu hefur áhrif á lestraráhugahvötina, svo sem samvinna milli nemenda (Guthrie og Humenick, 2004; Monteiro, 2013), val á lesefni (Morrow, 1992), lestur skáldsagna (McGeown, Duncan, Griffiths og Stothard, 2014), markmiðasetning (Wentzel, 1993) og stuðningur foreldra og vina (Katzir, Lesaux og Kim, 2009; Klauda og Wigfield, 2012).

\section{Styrkleikar og takmarkanir}

Eins og fram hefur komið er pessi grein byggð á hluta af gögnum frá fyrstu tveimur árum viđamikillar rannsóknar á nemendum á miđstigi grunnskóla. Pegar gagnasöfnun lýkur verđur hægt að skođa nánar hvernig lestraráhugahvöt próast hjá nemendum á miðstigi og hvort tengsl við lesskilning breytast međ aldrinum. Einnig verđur unnt að skođa útkomu sömu nemenda á samræmdum könnunarprófum og hugsanleg tengsl við lestraráhugahvöt. Í peim fjölda rannsókna sem gerđar hefur verið á lestraráhugahvöt eru notuð mismunandi mælitæki byggð á ólíkum kenningum um áhugahvöt. pví parf ađ túlka niðurstöđur pessarar rannsóknar með tilliti til kenningarinnar um frammistöđumarkmið sem mælitækið er byggt á (Ames, 1992; Elliott og Dweck, 1988; Nicholls, 1984, 1989).

\section{LOKAORĐ}

prátt fyrir takmarkanir á rannsókninni geta niðurstöđur okkar ekki ađeins sýnt fræðasamfélaginu vel birtingarmynd lestraráhugahvatar og tengsl lestraráhugahvatar og lesskilnings heldur einnig gefið kennurum og foreldrum mikilvægar vísbendingar um pađ hversu mikilvægt er að ýta undir lestraráhuga barna. Ljóst er að lestrarfælni eykst milli ára og pví er mikilvægt að sporna við slíkri hegðun hjá nemendum.

\section{ATHUGASEMD}

Við viljum færa nemendum og kennurum sem pátt tóku í rannsókninni kærar pakkir fyrir framlag peirra, án peirra hefđi pessi rannsókn aldrei orđið að veruleika. Verkefnið er styrkt af Rannsóknarmiðstöð Íslands. Rannsóknin var gerð með leyfi Vísindasiðanefndar nr. VSN S7178 og tilkynnt til Persónuverndar. 


\section{HEIMILDIR}

Almar M. Halldórsson. (2006). Lesskilningur og íslenskukunnátta 15 ára nemenda: Sérstađa Íslands og forspárpættir: Niðurstöđur PISA 2000 og samræmdra prófa. Reykjavík: Námsmatsstofnun. Sótt af https://rafhladan.is/bitstream/handle/10802/11062/ skyrsla_almar.pdf?sequence=1

Almar M. Halldórsson. (2011). Kynjamunur í námsárangri í grunnskólum í Reykjavík samkvæmt PISA 2009 og samræmdum prófum. Reykjavík: Menntasvið Reykjavíkur.

Almar M. Halldórsson og Ragnar F. Ólafsson. (2016). Helstu niđurstöđur PISA 2015. Reykjavík: Menntamálastofnun. Sótt af https://mms.is/sites/mms.is/files/pisa_2015_island. pdf

Almar M. Halldórsson, Ragnar F. Ólafsson og Júlíus K. Björnsson. (2013). Helstu niðurstöđur PISA 2012: Læsi nemenda á stærðfræđi, náttúrufræđi og lesskilningur. Reykjavík: Námsmatsstofnun.

Amalía Björnsdóttir, Baldur Kristjánsson og Börkur Hansen. (2008). Námsáhugi nemenda í grunnskólum: Hver er hann að mati nemenda og foreldra? Hvernig breytist hann eftir aldri og kyni? Tímarit um menntarannsóknir, 5, 7-26. Sótt af http://skemman.is/ stream/get/1946/15126/36621/1/1_amalia_baldur_borkur1.pdf

Ames, C. (1992). Classrooms: Goals, structures, and student motivation. Journal of Educational Psychology, 84(3), 261-271. https://doi.org/10.1037//0022-0663.84.3.261

Baker, L. og Wigfield, A. (1999). Dimensions of children's motivation for reading and their relations to reading activity and reading achievement. Reading Research Quarterly, 34(4), 452-477. https://doi.org/10.1598/rrq.34.4.4

Bandura, A. (1986). Social foundations of thought and action. Englewood Cliffs: Prentice Hall.

Bandura, A. (2006). Guide for constructing self-efficacy scales. Í F. Pajares og T. Urdan (ritstjórar), Self-efficacy beliefs of adolescents (bls. 307-337). Greenwich: Information Age.

Becker, M., McElvany, N. og Kortenbruck, M. (2010). Intrinsic and extrinsic reading motivation as predictors of reading literacy: A longitudinal study. Journal of Educational Psychology, 102(4), 773-785. https://doi.org/10.1037/a0020084

Bozack, A. R. og Salvaggio, A. N. (2013). Relational effects of reading motivation and academic achievement among adolescent boys. Reading Psychology, 34(6), 507-522. https://doi.org/10.1080/02702711.2012.660302

Brynhildur Pórarinsdóttir og Póroddur Bjarnason. (2010). Bóklestur íslenskra unglinga í alpjóđlegu ljósi. Í Gunnar Pór Jóhannesson og Helga Björnsdóttir (ritstjórar), Rannsóknir í félagsvísindum XI, Félags- og mannvísindadeild: Erindi flutt á ráđstefnu í október 2010 (bls. 40-50). Reykjavík: Félagsvísindastofnun Háskóla Íslands.

Byrnes, J. P. og Wasik, B. A. (2009). Language and literacy development: What educators need to know. New York: Guilford Press.

Cain, K. (2010). Reading development and difficulties. Chichester: Blackwell.

Cain, K. og Oakhill, J. (2006). Profiles of children with specific reading comprehension difficulties. British Journal of Educational Psychology, 76(4), 683-696. https://doi.org/ 10.1348/000709905x67610

Cartwright, K. B. (2009). The role of cognitive flexibility in reading comprehension: Past, present, and future. Í S. E. Israel og G. Duffy (ritstjórar), Handbook of research on reading comprehension (bls. 115-139). New York: Routledge. 
Cartwright, K. B., Marshall, T. R. og Wray, E. (2015). A longitudinal study of the role of reading motivation in primary students' reading comprehension: Implications for a less simple view of reading. Reading Psychology, 37(1), 55-91. https://doi.org/10.108 $0 / 02702711.2014 .991481$

Chapman, J. W. og Tunmer, W. E. (1995). Development of young children's reading self-concepts: An examination of emerging subcomponents and their relationship with reading achievement. Journal of Educational Psychology, 87(1), 154-167. https:// doi.org/10.1037/0022-0663.87.1.154

Chiu, M. M. og McBride-Chang, C. (2006). Gender, context, and reading: A comparison of students in 43 countries. Scientific Studies of Reading, 10(4), 331-362. https://doi. org/10.1207/s1532799xssr1004_1

Cochran, W. G. (2007). Sampling techniques (3. útgáfa). New York: Wiley.

Cunningham, A. E. og Stanovich, K. E. (1997). Early reading acquisition and its relation to reading experience and ability 10 years later. Developmental Psychology, 33(6), 934945. https://doi.org/10.1037/0012-1649.33.6.934

Dweck, C. S. (2002). The development of ability conceptions. Í A. Wigfield og J. S. Eccles (ritstjórar), Development of achievement motivation (bls. 57-88). San Diago: Academic Press.

Eccles, J. S. (1983). Expectancies, values, and academic behaviors. Í J. T. Spence (ritstjóri), Achievement and achievement motives: Psychological and sociological approaches (bls. 75-146). San Francisco: Freeman.

Elley, W. B. (ritstjóri). (1994). The IEA study of reading literacy: Achievement and instruction in thirty-two school systems. Oxford: Pergamon Press.

Elliott, E. S. og Dweck, C. S. (1988). Goals: An approach to motivation and achievement. Journal of Personality and Social Psychology, 54(1), 5-12. https://doi.org/10.1037/ 0022-3514.54.1.5

Elsa Lyng Magnúsdóttir, Steinunn Gestsdóttir og Kristján Ketill Stefánsson. (2013). Tengsl skólatengdrar hvatningar við trú ungmenna á eigin getu til sjálfstjórnunar í námi. Net/a - Veftímarit um uppeldi og menntun: Sérrit 2013 - Fagið og fræđin. Sótt af http:// netla.hi.is/serrit/2013/fagid_og_fraedin/002.pdf

Gambrell, L. B. (1996). Creating classroom cultures that foster reading motivation. The Reading Teacher, 50(1), 14-25.

Gambrell, L. B. (2011). Seven rules of engagement: What's most important to know about motivation to read. The Reading Teacher, 65(3), 172-178. https://doi.org/10.1002/ trtr.01024

Gambrell, L. B., Palmer, B. M., Codling, R. M. og Mazzoni, S. A. (1996). Assessing motivation to read. The Reading Teacher, 49(7), 518-533.

Garton, A. og Pratt, C. (1989). Learning to be literate: The development of spoken and written language. Oxford: Blackwell.

Guthrie, J. T. og Cox, K. E. (2001). Classroom conditions for motivation and engagement in reading. Educational Psychology Review, 13(3), 283-302.

Guthrie, J. T. og Greaney, V. (1991). Literacy acts. Í R. Barr, M. L. Kamil, P. B. Mosenthal og P. D. Pearson (ritstjórar), Handbook of reading research (2. bindi, bls. 68-96). New York: Longman. 
Guthrie, J. T., Hoa, A. L. W., Wigfield, A., Tonks, S. M., Humenick, N. M. og Littles, E. (2007). Reading motivation and reading comprehension growth in the later elementary years. Contemporary Educational Psychology, 32(3), 282-313. https://doi.org/ 10.1016/j.cedpsych.2006.05.004

Guthrie, J. T. og Humenick, N. M. (2004). Motivating students to read: Evidence for classroom practices that increase reading motivation and achievement. Í P. McCardle og V. Chhabra (ritstjórar), The voice of evidence in reading research (bls. 329-354). Baltimore: Brookes.

Guthrie, J. T. og Wigfield, A. (2000). Engagement and motivation in reading. Í M. L. Kamil, P. B. Mosenthal, P. D. Pearson og R. Barr (ritstjórar), Handbook of reading research (3. bindi, bls. 403-422). Mahwah: Erlbaum.

Guthrie, J. T., Wigfield, A., Metsala, J. L. og Cox, K. E. (1999). Motivational and cognitive predictors of text comprehension and reading amount. Scientific Studies of Reading, 3(3), 231-256. https://doi.org/10.1207/s1532799xssr0303_3

Guthrie, J. T., Wigfield, A. og Perencevich, K. C. (ritstjórar). (2004). Motivating reading comprehension: Concept-oriented reading instruction. Mahwah: Erlbaum.

Guthrie, J. T., Wigfield, A. og VonSecker, C. (2000). Effects of integrated instruction on motivation and strategy use in reading. Journal of Educational Psychology, 92(2), 331341. https://doi.org/10.1037/0022-0663.92.2.331

Hamilton, E. W., Nolen, S. B. og Abbott, R. D. (2013). Developing measures of motivational orientation to read and write: A longitudinal study. Learning and Individual Differences, 28, 151-166. https://doi.org/10.1016/j.lindif.2013.04.007

Henk, W. A, Bottomley, D. M. og Melnick, S. A. (1996). Preliminary validation of the writer self-perception scale. Í E. G. Sturtevant, W. M. Linek, V. P. Duling og D. Deal (ritstjórar), Growing literacy (bls. 188-199). Pittsburg: College Reading Association.

Hoover, W. A. og Gough, P. B. (1990). The simple view of reading. Reading and Writing, 2(2), 127-160. https://doi.org/10.1007/bf00401799

Karl Fannar Gunnarsson og Sigurgrímur Skúlason. (2009, febrúar). Kynning á gerđ og niđurstöđum rannsóknar- og stöđuprófs í lestri fyrir 4. til 7. bekk. Fyrirlestur á ráđstefnu Félags um menntarannsóknir, Reykjavík.

Katzir, T., Lesaux, N. K. og Kim, Y.-S. (2009). The role of reading self-concept and home literacy practices in fourth grade reading comprehension. Reading and Writing, 22(3), 261-276. https://doi.org/10.1007/s11145-007-9112-8

Klauda, S. L. og Wigfield, A. (2012). Relations of perceived parent and friend support for recreational reading with children's reading motivations. Journal of Literacy Research, 44(1), 3-44. https://doi.org/10.1177/1086296x11431158

Linnenbrink, E. A. og Pintrich, P. R. (2002). Motivation as an enabler for academic success. School Psychology Review, 31(3), 313-327.

Logan, S. og Johnston, R. (2009). Gender differences in reading ability and attitudes: Examining where these differences lie. Journal of Research in Reading, 32(2), 199-214. https://doi.org/10.1111/j.1467-9817.2008.01389.x

Logan, S. og Medford, E. (2011). Gender differences in the strength of association between motivation, competency beliefs and reading skill. Educational Research, 53(1), 85-94. https://doi.org/10.1080/00131881.2011.552242 
Logan, S., Medford, E. og Hughes, N. (2011). The importance of intrinsic motivation for high and low ability readers' reading comprehension performance. Learning and Individual Differences, 21(1), 124-128. https://doi.org/10.1016/j.lindif.2010.09.011

Lohr, S. (2009). Sampling: Design and analysis. Boston: Brooks/Cole.

Luke, A. og Freebody, P. (1999). Further notes on the Four Resources Model. Sótt af https://pdfs.semanticscholar.org/a916/0ce3d5e75744de3d0ddacfaf6861fe928b9e. pdf

Majid, S., og Tan, V. (2007). Understanding the reading habits of children in Singapore. Journal of Educational Media \& Library Sciences, 45(2), 187-198.

Marinak, B. A. og Gambrell, L. B. (2010). Reading motivation: Exploring the elementary gender gap. Literacy Research and Instruction, 49(2), 129-141. https://doi. org/10.1080/19388070902803795

Marzano, R. J. (2004). Building background knowledge for academic achievement: Research on what works in schools. Alexandria: ASCD.

McCoach, D. B., O'Connell, A. A., Reis, S. M. og Levitt, H. A. (2006). Growing readers: A hierarchical linear model of children's reading growth during the first 2 years of school. Journal of Educational Psychology, 98(1), 14-28. https://doi.org/10.1037/00220663.98.1.14

McElvany, N., Kortenbruck, M. og Becker, M. (2008). Lesekompetenz und Lesemotivation: Entwicklung und Mediation des Zusammenhangs durch Leseverhalten [Reading competence and reading motivation: Their development and the mediation of their relationship by reading behavior]. Zeitschrift für Pädagogische Psychologie, 22(34), 207-219. https://doi.org/10.1024/1010-0652.22.34.207

McGeown, S., Duncan, L. G., Griffiths, Y. M. og Stothard, S. E. (2014). Exploring the relationship between adolescents' reading skills, reading motivation and reading habits. Reading and Writing, 28(4), 1-25. https://doi.org/10.1007/s11145-014-9537-9

McKenna, M. C., Kear, D. J. og Ellsworth, R. A. (1995). Children's attitudes toward reading: A national survey. Reading Research Quarterly, 30(4), 934-956. https://doi.org/10. 2307/748205

Mennta- og menningamálaráđuneyti. (2012). Ađalnámskrá grunnskóla 2011: Almennur hluti. Reykjavík: Höfundur.

Millard, E. (1997). Differently literate: Gender identity and the construction of the developing reader. Gender and Education, 9(1), 31-48. https://doi.org/10.1080 /09540259721439

Monteiro, V. (2013). Promoting reading motivation by reading together. Reading Psychology, 34(4), 301-335. https://doi.org/10.1080/02702711.2011.635333

Morgan, P. L. og Fuchs, D. (2007). Is there a bidirectional relationship between children's reading skills and reading motivation? Exceptional Children, 73(2), 165-183. https:// doi.org/10.1177/001440290707300203

Morrow, L. M. (1992). The impact of a literature-based program on literacy achievement, use of literature, and attitudes of children from minority backgrounds. Reading Research Quarterly, 27(3), 250-275. https://doi.org/10.2307/747794

Mullis, I. V. S., Martin, M. O., Kennedy, A. M. og Foy, P. (2007). PIRLS 2006 international report: IEA's progress in international reading literacy study in primary schools in 40 
countries. Chestnut Hill: TIMSS \& PIRLS International Study Center. Sótt af http://timss. bc.edu/PDF/PIRLS2006_international_report.pdf

Nicholls, J. G. (1984). Achievement motivation: Conceptions of ability, subjective experience, task choice, and performance. Psychological Review, 91(3), 328-346. https:// doi.org/10.1037//0033-295x.91.3.328

Nicholls, J. G. (1989). The competitive ethos and democratic education. Cambridge: Harvard University Press.

Nurmi, J.-E. og Aunola, K. (2005). Task-motivation during the first school years: A personoriented approach to longitudinal data. Learning and Instruction, 15(2), 103-122. https://doi.org/10.1016/j.learninstruc.2005.04.009

Oakhill, J. V., og Cain, K. (2012). The precursors of reading ability in young readers: Evidence from a four-year longitudinal study. Scientific Studies of Reading, 16(2), 91121. https://doi.org/10.1080/10888438.2010.529219

Oakhill, J. V. og Petrides, A. (2007). Sex differences in the effects of interest on boys' and girls' reading comprehension. British Journal of Psychology, 98(2), 223-235. https:// doi.org/10.1348/000712606×117649

OECD. (2010). PISA 2009 results: What students know and can do: Student performance in reading, mathematics and science (1. bindi). Paris: Höfundur.

Perfetti, C. A., Landi, N. og Oakhill, J. (2005). The acquisition of reading comprehension skill. Í M. J. Snowling og C. Humle (ritstjórar), The science of reading: A handbook (bls. 227-247). Oxford: Blackwell.

Pintrich, P. R. og Schunk, D. H. (2002). Motivation in education: Theory, research, and applications (2 útgáfa). Upper Saddle River: Prentice-Hall.

Rapp, D. N., van den Broek, P., McMaster, K. L., Kendeou, P. og Espin, C. A. (2007). Higher-order comprehension processes in struggling readers: A perspective for research and intervention. Scientific Studies of Reading, 11(4), 289-312. https://doi. org/10.1080/10888430701530417

Ryan, R. M. og Deci, E. L. (2000). Self-determination theory and the facilitation of intrinsic motivation, social development, and well-being. American Psychologist, 55(1), 68-78. https://doi.org/10.1037//0003-066x.55.1.68

Scarborough, H. S. (2009). Connecting early language and literacy to later reading (dis)abilities: Evidence, theory, and practice. Í F. Fletcher-Campbell, J. M. Soler og G. Reid (ritstjórar), Approaching difficulties in literacy development: Assessment, pedagogy and programmes (bls. 23-38). London: SAGE.

Schiefele, U., Schaffner, E., Möller, J., Wigfield, A., Nolen, S. og Baker, L. (2012). Dimensions of reading motivation and their relation to reading behavior and competence. Reading Research Quarterly, 47(4), 427-463.

Snow, C. E. (2002). Reading for understanding: Toward an R\&D program in reading comprehension. Santa Monica: Rand.

Taboada, A., Tonks, S. M., Wigfield, A. og Guthrie, J. T. (2009). Effects of motivational and cognitive variables on reading comprehension. Reading and Writing, 22(1), 85-106. https://doi.org/10.1007/s11145-008-9133-y

Unesco. (e.d.). Literacy. Sótt af www.unesco.org/new/en/education/themes/education-building-blocks/literacy/ 
Usher, E. L. og Pajares, F. (2006). Sources of academic and self-regulatory efficacy beliefs of entering middle school students. Contemporary Educational Psychology, 31(2), 125-141. https://doi.org/10.1016/j.cedpsych.2005.03.002

van den Broek, P. og Kremer, K. E. (2000). The mind in action: What it means to comprehend during reading. Í B. M. Taylor, M. F. Graves og P. van den Broek (ritstjórar), Reading for meaning: Fostering comprehension in the middle grades (bls. 1-31). New York: Teachers College Press.

Wang, J. H.-Y. og Guthrie, J. T. (2004). Modeling the effects of intrinsic motivation, extrinsic motivation, amount of reading, and past reading achievement on text comprehension between U.S. and Chinese Students. Reading Research Quarterly, 39(2), 162-186. https://doi.org/10.1598/rrq.39.2.2

Wentzel, K. R. (1993). Motivation and achievement in early adolescence: The role of multiple classroom goals. The Journal of Early Adolescence, 13(1), 4-20. https://doi. org/10.1177/0272431693013001001

Wigfield, A., Eccles, J. S., Yoon, K. S., Harold, R. D., Arbreton, A. J., Freedman-Doan, C. og Blumenfeld, P. C. (1997). Change in children's competence beliefs and subjective task values across the elementary school years: A 3-year study. Journal of Educational Psychology, 89(3), 451-469. https://doi.org/10.1037/0022-0663.89.3.451

Wigfield, A. og Guthrie, J. T. (1997). Relations of children's motivation for reading to the amount and breadth or their reading. Journal of Educational Psychology, 89(3), 420432. https://doi.org/10.1037//0022-0663.89.3.420

Zimmerman, B. J. og Martinez-Pons, M. (1988). Construct validation of a strategy model of student self-regulated learning. Journal of Educational Psychology, 80(3), 284-290. https://doi.org/10.1037//0022-0663.80.3.284

Greinin barst tímaritinu 2. febrúar 2018 og var sampykkt til birtingar 25. nóvember 2018

\section{UM HÖFUNDANA}

Hafdís Guđrún Hilmarsdóttir (hgh16@hi.is) er doktorsnemi við kennaradeild Menntavísindasviðs Háskóla Íslands. Hún lauk M.Ed.-prófi í kennslufræðum frá Háskóla Íslands áriđ 2013. Hún starfar sem sérfræđingur í læsi hjá Menntamálastofnun. Áhugasvið hennar snýr ađ rannsóknum á lestraráhugahvöt og læsi.

Freyja Birgisdóttir (freybi@hi.is) er dósent í proskasálfræđi við sálfræđideild Heilbrigđisvísindasviđs Háskóla Íslands. Hún lauk doktorsprófi í proskasálfræđi frá Oxford-háskóla árið 2003. Meginrannsóknarsvið hennar er próun lestrar, lesskilnings og ritunar og tengsl við önnur svið proska, svo sem áhugahvöt og sjálfstjórn.

Steinunn Gestsdóttir (steinuge@hi.is) er prófessor við sálfræđideild Heilbrigđisvísindasviđs Háskóla Íslands. Hún lauk doktorsprófi frá Tufts-háskóla í Bandaríkjunum 2005. Rannsóknir hennar snúa að próun sjálfstjórnunar (e. self-regulation) og hvernig hún tengist proskaframvindu barna og ungmenna, sérstaklega ađlögun barna ađ grunnskóla og æskilegum proska ungmenna. 


\title{
The effect of reading motivation on reading comprehension among early adolescents in Iceland
}

\begin{abstract}
Previous studies indicate that reading motivation is critical for the attainment of various aspects of literacy. Consistently, a strong relationship has been shown to exist between poor reading motivation, reading avoidance and early failure in reading (Bozack \& Salvaggio, 2013). Research also indicates a gender gap in reading motivation, with girls having significantly more motivation to read than boys at various age levels (Marinak \& Gambrell, 2010; Wigfield \& Guthrie, 1997). This difference has been proposed as one of the key factors contributing to the gender disparities in reading achievement that usually emerge in school later. As in many other cultures, reading comprehension among Icelandic youth has been steadily declining over the past years (Almar M. Halldórsson \& Ragnar F. Ólafsson, 2016) with $21 \%$ of Icelandic students being incapable of comprehending or enjoying their reading (OECD, 2010). However, despite evidence supporting the importance of reading motivation for reading achievement, few studies have assessed reading motivation among Icelandic speaking children and its effects on later reading skills.
\end{abstract}

The present study aimed to fill this gap in research by exploring the reading motivation of Icelandic-speaking girls and boys in 5th and 6th Grade and its predictive effect on their reading comprehension skills a year later. We also explored the validity and reliability of a recent Icelandic version of a measure of motivational orientation to read (Hamilton et al., 2013), but, until now, no such measures have existed for use among Icelandicspeaking children. Participants comprised a stratified sample of 4005 th Graders from 24 classes in 8 schools in the Reykjanes peninsula and the Reykjavík capital area. Among these, 179 were boys. The children were assessed on reading motivation in Grades 5 and 6 , and their scores related to their reading comprehension skills in Grade 6 . The reading motivational orientation questionnaire was used to measure the students' reading motivation (Hamilton et al., 2013). The questionnaire comprised 18 items intended to measure Reading Mastery Orientation, Reading Interest Orientation, Reading Ego Orientation and Reading Avoidance. The items reflect Nicholls $(1984,1989)$ theory by asking students how they feel when they read. A reading comprehension test from the Icelandic Educational Testing Institute (Karl Fannar Gunnarsson \& Sigurgrímur Skúlason, 2009) was used to assess the students' reading comprehension. The test had a multiple-choice format and consisted of two texts, one narrative text and one expository text. Analyses of the reading motivation orientations scale indicated an acceptable internal consistency and showed expected relations to other related constructs, providing support for the scale to be used in an Icelandic context. The results of the study indicated relative stability of reading motivation across Grades 5 and 6 and that both girls and boys rate performance based reading motivation orientation goals higher than goals based on ego orientations. Significant gender differences emerged on three of the four subscales of the reading 
motivation orientation questionnaire with girls scoring higher than boys on the reading mastery and interest orientations, and boys scoring higher on reading avoidance. Mastery and interest in Grade 5 also positively predicted reading comrephension in Grade 6 , and reading avoidance negatively predicted reading comprehension in Grade 6 . The results further revealed that reading motivation in Grade 5 explained $5 \%$ of the variance in reading comprehension in Grade 6, after controlling for previous reading comprehension performance. These results add to our understanding of reading motivations among Icelandic students and further underline the importance of reading motivation in later reading comprehension.

Keywords: reading motivation, reading comprehension, adolescents' reading, gender differences

\section{ABOUT THE AUTHORS}

Hafdis Gudrun Hilmarsdottir (hgh16@hi.is) is a Ph.D. student at the School of Education, University of Iceland and working at the Icelandic Directorate of Education as an expert in reading and literacy. She completed her master's degree at the School of Education, University of Iceland in 2013. Her primary field of research in her doctoral studies is reading motivation and its relationship to literacy.

Freyja Birgisdottir (freybi@hi.is) is an associate professor of psychology at the University of Iceland. She completed her doctoral degree in developmental psychology from the University of Oxford in 2003. Her main research interests are the development of reading and writing and its connection to other fields of development, including motivation and self-regulation.

Steinunn Gestsdottir (steinuge@hi.is) is a professor of psychology at the University of Iceland. She completed her doctoral degree from Tufts University in 2005. Her research has focused on the development of intentional self-regulation, in particular, how selfregulation relates to successful adaptation to school and to the positive development of youth. 


\section{VIĐAUKI}

Mælitæki fyrir lestraráhugahvöt (Mjög sammála, frekar sammála, frekar ósammála, mjög ósammála):

Mér líđur best ...

Lestraráhugi

1) pegar ég les um eitthvađ mjög áhugavert

2) pegar ég les sögu eđa bók sem ég hef virkilega gaman af

3) pegar ég les mína uppáhalds tegund af bók

4) pegar ég hef mikinn áhuga á pví sem ég les

5) pegar ég les eitthvað sem er mjög spennandi

Lestrarleikni

6) ef ég get lesið lengri og erfiðari bækur en ég gat áður lesið

7) ef ég get lesið eitthvað erfitt með pví að leggja hart að mér

8) ef ég skil að lokum mjög flókna hugmynd

9) ef ég get lesið eitthvað erfitt og skilið pað

Lestrarsjálf

10) ef ég fæ eina af hæstu einkunnunum í bekknum

11) ef ég sýni fólki ađ ég sé klár

12) ef ég sýni fólki að ég sé góđur lesandi

13) ef enginn bendir á villur sem ég geri í lestri

14) ef ég get lesið pyngri bækur en aðrir nemendur Lestrarfælni

15) ef ég get hangsað í stað pess að lesa

16) ef ég les bara smávegis og kemst upp međ pað

17) ef ég parf ekki að gera neina heimavinnu í lestri

18) ef allur lesturinn er auðveldur 